\title{
Evidence for Defective Transmembrane Signaling in B Cells from Patients with Wiskott-Aldrich Syndrome
}

\author{
Hans-Uwe Simon, * Gordon B. Mills, ${ }^{\star}$ Shuichi Hashimoto, ${ }^{\star}$ and Katherine A. Siminovitch * \\ Departments of Medicine, Immunology, Molecular and Medical Genetics and Obstetrics, University of Toronto; *Samuel Lunenfeld \\ Research Institute, Mount Sinai Hospital, Toronto, Ontario, Canada M5G 1X5; and ${ }^{\ddagger}$ Oncology Research, \\ Toronto General Hospital, Toronto, Ontario, Canada M5G 1 X5
}

\begin{abstract}
B lymphocytes from patients expressing the $X$ chromosomelinked immune deficiency disorder, Wiskott-Aldrich syndrome (WAS), fail to produce antibodies in response to stimulation with polysaccharides and other type- $2 \mathrm{~T}$ cell-independent antigens. To investigate whether this abnormality reflects a defect in the signal transduction cascade normally triggered by ligation of surface immunoglobulin ( $\mathrm{sIg}$ ) on B cells, we have examined early signaling events induced by anti-Ig antibody stimulation of EBV B lymphoblastoid cell lines from WAS patients and healthy controls. Despite the expression of comparable levels of sIg and sIgM on WAS and control EBV B cells, WAS cells failed to manifest the increased proliferation in response to anti-Ig treatment observed in the control cell lines. WAS and control EBV B cells also differed in the magnitude of the change in cytosolic free calcium $\left(\left[\mathrm{Ca}^{2+}\right]_{i}\right)$ induced by sIg ligation; WAS cells showed either markedly diminished or no changes in $\left[\mathrm{Ca}^{2+}\right]_{i}$ levels whereas control EBV B cells consistently showed increases in $\left[\mathrm{Ca}^{2+}\right]_{i}$. Anti-Ig-induced changes in inositol phosphate release were also markedly reduced in WAS compared with control cells. As protein tyrosine phosphorylation is thought to represent a proximal event in the activation of $B$ cells, inducing increases in $\left[\mathrm{Ca}^{2+}\right]_{i}$ by virtue of tyrosine phosphorylation of phospholipase C (PLC) $-\gamma$, profiles of protein tyrosine phosphorylation and expression of tyrosine-phosphorylated PLC- $\gamma 1$ were compared between WAS and normal EBV $B$ cells before and after sIg cross-linking. These studies revealed that in addition to defective mobilization of $\mathrm{Ca}^{2+}$, the WAS cells manifested little or no increase in tyrosine phosphorylation of PLC- $\gamma 1$ or other intracellular proteins after sIg ligation. Together these results indicate the association of WAS with a defect in the coupling of sIg to signal transduction pathways considered prerequisite for $B$ cell activation, likely at the level of tyrosine phosphorylation. The abnormalities observed in these early transmembrane signaling events in WAS EBV B cells may play a role not only in the nonresponsiveness of WAS patient $B$ cells to certain $T$ independent antigens, but also in the genesis of some of the other cellular deficits exhibited by these patients. (J. Clin. Invest. 1992. 90:1396-1405.) Key words: B cell signal transduction - immunodeficiency • Wiskott-Aldrich syndrome
\end{abstract}

Address correspondence to Dr. K. A. Siminovitch, Mount Sinai Hospital, Toronto, Room 656A, 600 University Avenue, Toronto, Ontario, Canada M5G 1 X5.

Received for publication 24 September 1991 and in revised form 19 February 1992.

J. Clin. Invest.

(c) The American Society for Clinical Investigation, Inc.

$0021-9738 / 92 / 10 / 1396 / 10 \quad \$ 2.00$

Volume 90, October 1992, 1396-1405

\section{Introduction}

The Wiskott-Aldrich syndrome (WAS) ${ }^{1}$ is an X chromosome-linked recessive disorder associated with severe thrombocytopenia, eczema, impaired humoral and cellular immunity, and increased susceptibility to lymphoid malignancies ( 1 , 2 ). The immune abnormalities are variably expressed among affected boys, but the most characteristic include absent antibody responses to polysaccharide antigens and a progressive decline in $\mathrm{T}$ cell functions, such as delayed hypersensitivity and allograft rejection (2-4). The molecular and biochemical defects responsible for WAS are unknown and the lack of such information has interfered with precise definition of the cellular basis for the immune deficit. Although this later facet of the syndrome was at one time ascribed primarily to an intrinsic defect of $T$ cells, more recent data suggest that the B cells of WAS patients are also intrinsically abnormal. For example, compared with healthy controls WAS patients manifest reduced numbers of $\mathrm{CD} 23^{+}$and increased numbers of $\mathrm{CD} 20^{+}$ CD21- B cells within their peripheral B lymphocyte populations (5). An intrinsic $B$ as well as T cell defect in WAS is also implied, albeit indirectly, by the detection of nonrandom $X$ chromosome inactivation patterns in both $\mathrm{B}$ and $\mathrm{T}$ lymphocytes of female WAS carriers $(6,7)$. Lastly, our recent finding of abnormal expression of a developmentally regulated glycosyltransferase activity in both EBV B lymphoblastoid and T cells from WAS patients suggests that the immune abnormalities observed in these patients reflect both $B$ and $T$ cell dysfunction and possibly a defect in lymphocyte maturation (8).

Although WAS patients are unable to produce antibodies to polysaccharides and other $T$ cell-independent type 2 antigens, their B cells do respond to T cell-independent type 1 antigens, such as TNP-Brucella abortus (9). A similar pattern of immune responsiveness has been described in human neonatal B cells as well as in the B cells of CBA/N mice, a strain that carries an $\mathrm{X}$ chromosome-linked immunodeficiency (xid) mutation associated with the absence of a major subpopulation of mature B cells (10). In contrast to WAS, the xid mutation does not appear to affect $T$ cells and platelets. However, the impaired maturation and hyporesponsiveness to type 2 antigens found in CBA/N xid male and homozygous female mice suggest that the effects of the xid and WAS mutations on B cells are similar and that data relating to the properties of xid B cells may provide clues into the basic cell defects underlying immune dysfunction in WAS.

1. Abbreviations used in this paper: $\left[\mathrm{Ca}^{2+}\right]_{\mathrm{i}}$, cytosolic-free calcium concentration; PLC, phospholipase C; sIg, surface Ig; TBS, Tris-buffered saline; WAS, Wiskott-Aldrich syndrome; xid, X chromosome-linked immunodeficiency. 
In recent years increased knowledge of the biochemical pathways linking antigen/mitogen stimulation to lymphocyte activation and proliferation has rendered examination of the molecular mechanisms whereby these cells respond or fail to respond to particular mitogenic stimuli possible. It is now understood, for example, that in normal B cells, cross-linking of surface immunoglobulin ( $\mathrm{sIg}$ ) by anti-Ig antibody triggers the activation of specific tyrosine kinases resulting in the rapid tyrosine phosphorylation of various intracellular proteins including phospholipase C (PLC) (11-13). Ligation of sIg on B cells also evokes hydrolysis of phosphatidylinositol biphosphate by the enzyme PLC with the consequent generation of inositol-triphosphate and diacylglycerol. These latter molecules serve as second messengers in this signal transduction pathway, diacylglycerol inducing the activation and membrane translocation of protein kinase $\mathrm{C}$ and inositol-triphosphate stimulating release of ionized calcium $\left(\mathrm{Ca}^{2+}\right)$ from intracellular stores (14). In normal B cells, the bifurcating phosphoinositide signaling pathway, in conjunction with protein tyrosine phosphorylation, represent key components of a cascade of intracellular events, triggered by sIg receptor engagement and culminating in cell activation. By contrast, recent data from several groups suggest that these early signaling events are impaired in $B$ cells of CBA/N mice, such that cross-linking of sIg receptors induces markedly less inositol phospholipid hydrolysis and intracellular $\mathrm{Ca}^{2+}$ mobilization than that observed in normal B cells $(15,16)$. The basis for this signaling defect is unclear, although it appears to be associated with a quantitative or qualitative defect in PLC activity (16). In any case, these results raise the possibility that hyporesponsiveness of the transmembrane signaling apparatus may also occur in B cells of WAS patients and account for some of their immune dysfunction.

In this report, we have investigated transmembrane signaling events in anti-Ig-treated EBV immortalized B cell lines derived from WAS patients and healthy controls. The effect of anti-Ig stimulation on intracellular $\mathrm{Ca}^{2+}$ release, inositol phosphate production, and tyrosine phosphorylation was examined in light of recent data suggesting that the tyrosine phosphorylation of PLC is critical for sIg-induced activation of this enzyme and thus to the transduction of $\mathrm{Ca}^{2+}$-mobilizing signals after cross-linking of B cell $\operatorname{sIg}(12,13)$. The results of our studies indicate that the increases in cell proliferation, inositol phosphate production, and intracellular $\mathrm{Ca}^{2+}$ release that normally follow B cell sIg ligation are markedly reduced or absent in B cells of WAS patients. In addition, anti-Ig antibody-stimulated induction of tyrosine phosphorylation on intracellular proteins, including PLC- $\gamma 1$, was diminished in WAS compared with control B cells. These findings suggest that a defect in the signal transduction cascade is present in WAS B cells and may underlie, at least in part, their unresponsiveness to polysaccharides and certain other mitogenic stimuli.

\section{Methods}

Media and stock solutions. Complete culture medium was RPMI 1640 (Gibco, Gaithersburg, MD) supplemented with $2 \mathrm{mM}$ glutamine (Gibco), $5 \times 10^{2}$ M 2-mercaptoethanol (Sigma Chemical Co., St. Louis, MO), gentamycin (Sigma Chemical Co.), and 10\% FCS (Sterile Systems Inc., Logan, UT). Buffer A had the following composition $(\mathrm{mM}): 140 \mathrm{NaCl}, 3 \mathrm{KCl}, 1 \mathrm{MgCl}_{2}, 10$ glucose, $1 \mathrm{CaCl}_{2}$, and $20 \mathrm{Hepes}$, pH 7.23 (Sigma Chemical Co.). Ripa lysis buffer was $50 \mathrm{mM}$ Tris, pH $7.2 ; 150 \mathrm{mM} \mathrm{NaCl} ; 1 \%$ Nonidet P-40; $0.1 \%$ SDS; $0.1 \%$ sodium deoxy- cholate; $2 \mathrm{mM}$ EDTA; $10 \mu \mathrm{M}$ sodium orthovanadate; and $50 \mu \mathrm{M}$ $\mathrm{ZnCl}_{2}$. $\left[{ }^{3} \mathrm{H}\right]$ Thymidine $(6.7 \mathrm{Ci} / \mathrm{mM})$ was purchased from New England Nuclear (Lachine, Quebec). Indo-1 was from Molecular Probes Inc. (Eugene, OR). Ionomycin was from Calbiochem Corp. (La Jolla, CA). Unless stated otherwise, all other reagents were from Sigma Chemical Co.

Patients and preparation of $B$ cell lines. Peripheral blood was collected in heparin from 9 unrelated WAS patients, ranging in age from 2 to $25 \mathrm{yr}$, and from 16 age-matched healthy individuals. The nine WAS patients all showed the classical clinical triad of eczema, severe thrombocytopenia, and immune deficiency and each had a family history of this disorder. All patients were studied when not acutely ill or febrile. Mononuclear cells for the studies were obtained by density-gradient centrifugation over Ficoll-Hypaque. Because of difficulties in obtaining adequate numbers of freshly isolated B cells from WAS patients, most of the investigations of transmembrane signaling were performed using EBV-transformed B cell lines. EBV-immortalized cell lines were established by incubating $10^{7}$ mononuclear cells with $5 \mathrm{ml}$ supernatant of the $\mathrm{B} 95-8$ marmoset cell line at $37^{\circ} \mathrm{C}$ for $2 \mathrm{~h}$. The cells were distributed in 24-well culture plates and cultured in complete culture medium and $0.5 \mathrm{mg} / \mathrm{ml}$ cyclosporine $A$. The cell lines were subsequently maintained in complete culture medium. Cells were cultured in RPMI 1640 without FCS for $24 \mathrm{~h}$ before analysis of tyrosine phosphorylation.

Immunofluorescent analysis. EBV B cells $\left(1 \times 10^{6}\right)$ were washed twice with staining solution (PBS plus $0.1 \%$ BSA), and then incubated with either rabbit anti-human Ig (IgM, IgG, IgA, IgG-fraction; Organon Teknika, West Chester, PA), monoclonal anti-human IgM (Becton Dickinson Immunocytometry Systems, Mountain View, CA), or rabbit anti-human CD45 (IgG-fraction; Hybritech, Inc., San Diego, CA) antibody. After the first incubation $\left(30 \mathrm{~min}, 4^{\circ} \mathrm{C}\right)$, cells were washed twice with staining solution and were then incubated for $30 \mathrm{~min}$ at $4^{\circ} \mathrm{C}$ with FITC-conjugated goat anti-rabbit antibody (Gibco) or with FITC-conjugated goat anti-mouse antibody (Becton Dickinson Immunocytometry Systems). Background staining was assessed using a nonspecific primary antibody control (anti-TdT; Gibco) and was subtracted from values obtained on test samples. Alternatively, $1 \times 10^{6}$ EBV B cells were washed twice and stained directly by 30-min incubation at $4^{\circ} \mathrm{C}$ with either FITC-conjugated monoclonal anti-CD20 antibody or FITC-conjugated monoclonal IgG1 control antibody (Becton Dickinson Immunocytometry Systems). Cells were then washed twice, resuspended in $0.5 \mathrm{ml}$ staining solution, and examined by flow cytometry (EPICS-C; Coulter Electronics Inc., Hialeah, FL). For cell sorting, $20 \times 10^{6}$ mononuclear cells separated from peripheral blood of each of two WAS patients and two controls were incubated with monoclonal FITC-conjugated anti-CD20 antibody in $0.5 \mathrm{ml}$ staining solution and then applied to the cell sorter.

Proliferation assays. EBV B cells from patients and controls were resuspended at a concentration of $5 \times 10^{4}$ cells $/ \mathrm{ml}$ in RPMI 1640 containing $1 \%$ FCS and cultured in 0.2 -ml aliquots in flat-bottom microliter plates in the presence or absence of anti- $\operatorname{Ig}$ (at a final concentration of $5 \mu \mathrm{g} / \mathrm{ml}$ ). Cultures were maintained for either $24,48,72,96$, or $120 \mathrm{~h}$ and the cells were pulsed with $\left[{ }^{3} \mathrm{H}\right]$ thymidine $(2 \mu \mathrm{Ci} /$ well $) 4 \mathrm{~h}$ before termination of the incubation. $\left[{ }^{3} \mathrm{H}\right]$ thymidine incorporation was measured using an automated $\beta$ liquid-scintillation counter (Beckman). The maximal stimulation index was calculated as: $\operatorname{cpm}\left[{ }^{3} \mathrm{H}\right]-$ thymidine incorporation anti-Ig-treated cells $/ \mathrm{cpm}\left[{ }^{3} \mathrm{H}\right]$ thymidine incorporation untreated cells.

Intracellular calcium measurements. Intracellular ionized calcium concentration $\left(\left[\mathrm{Ca}^{2+}\right]_{i}\right)$ was measured as previously described (17). Briefly, either EBV-transformed B cells or freshly isolated unseparated or sorted CD20-positive peripheral blood lymphocytes were suspended at $5-10 \times 10^{6} / \mathrm{ml}$ in RPMI 1640 with $10 \% \mathrm{FCS}$ and $2.5 \mu \mathrm{g} / \mathrm{ml}$ indo- 1 acetoxymethyl ester for $30 \mathrm{~min}$ at $37^{\circ} \mathrm{C}$. Cells were then washed twice and resuspended at $1 \times 10^{6} / \mathrm{ml}$ in RPMI with $10 \%$ FCS. Immediately before analysis of $\left[\mathrm{Ca}^{2+}\right]_{i}$, cells were washed in buffer $\mathrm{A}$ and suspended $\left(10^{6}\right.$ cells in a volume of $\left.1.7 \mathrm{ml}\right)$ in a thermostatically controlled $\left(37^{\circ} \mathrm{C}\right)$ cuvette. Fluorescence emission was measured in a spectrophotometer (Hitachi F 4000; Hitachi Ltd., Tokyo, Japan ) using an excita- 
tion wavelength of $331 \mathrm{~nm}$ and an emission wavelength of $410 \mathrm{~nm}$. After equilibration of fluorescence to a stable baseline, the cells $\left(10^{6}\right)$ were stimulated with anti-Ig ( $10 \mu \mathrm{l}$ of a $1 \mathrm{mg} / \mathrm{ml}$ anti-Ig solution $)$ and fluorescence assessment was continued. Dependence on extracellular $\mathrm{Ca}^{2+}$ was analyzed using EBV B cells suspended in nominally $\mathrm{Ca}^{2+}$ free buffer A with $100 \mu \mathrm{M}$ EGTA, a solution calculated to contain $<10$ $\mathrm{nM}$ free $\mathrm{Ca}^{2+}$. Each analysis was calibrated by addition of $5 \mu \mathrm{M}$ ionomycin followed by $1 \mathrm{mM} \mathrm{Mn}{ }^{2+}$. $\left[\mathrm{Ca}^{2+}\right]_{\mathrm{i}}$ was calculated based on a $K_{\mathrm{m}}$ for Indo-1 at pH 7.2 of 180 as previously described (17).

In EBV B cells from healthy controls, peak $\left[\mathrm{Ca}^{2+}\right]_{i}$ levels were generally attained within 1-2 min after anti-Ig antibody addition and were considered representative of the anti-Ig-induced change in cytosolic free calcium $\left(\Delta\left[\mathrm{Ca}^{2+}\right]_{i}\right)$. As this initial peak was frequently not detected after cross-linking of sIg on EBV B cells from WAS patients (see below), the peak anti-Ig-induced $\Delta\left[\mathrm{Ca}^{2+}\right]_{i}$ in these latter cells was considered equivalent to the highest $\left[\mathrm{Ca}^{2+}\right]_{i}$ value observed in the first 2 min after antibody addition (see Table II).

Assay for inositol phosphate production. Analysis of inositol phosphate release was performed as previously described $(18,19)$. Briefly, 5 $\times 10^{7} \mathrm{EBV}$ B cells were incubated at $37^{\circ} \mathrm{C}$ in RPMI 1640 and labeled with [ ${ }^{3} \mathrm{H}$ ] myoinositol $(100 \mu \mathrm{Ci} /$ cells; New England Nuclear, Boston, MA). After a 16-h incubation, cells were washed twice and incubated for a further $15 \mathrm{~min}$ at $37^{\circ} \mathrm{C}$ in DME containing $20 \mathrm{mM}$ Hepes ( $\mathrm{pH}$ 7.5 ), $25 \mathrm{mM} \mathrm{LiCl}$, and $1 \mathrm{mg} / \mathrm{ml} \mathrm{BSA}$. Samples were then stimulated with $20 \mu \mathrm{g}$ anti-Ig or medium for $3 \mathrm{~min}$ at $37^{\circ} \mathrm{C}$. The reaction was terminated by addition of cold $5 \%$ perchloric acid and the inositol phosphates were extracted, diluted in $5 \mathrm{ml}$ of $\mathrm{H}_{2} \mathrm{O}$, and applied to AG1-X8 (Bio-Rad, Mississauga, Ontario) columns. Columns were washed with $20 \mathrm{ml} \mathrm{H}_{2} \mathrm{O}$ and a $20-\mathrm{ml}$ solution of $5 \mathrm{mM}$ sodium tetraborate and $60 \mathrm{mM}$ ammonium formate. $\left[{ }^{3} \mathrm{H}\right]$ inositol phosphates were eluted with a solution of $1.0 \mathrm{M}$ ammonium formate and $0.1 \mathrm{M}$ formic acid and quantified in duplicate samples by liquid-scintillation counting. Anti-Ig-induced release of inositol phosphates was calculated as: $\left[{ }^{3} \mathrm{H}\right]$ inositol phosphate formation in anti-Ig-treated cells $/\left[{ }^{3} \mathrm{H}\right]$ inositol phosphate formation in untreated cells.

Immunoprecipitation of $P L C-\gamma 1$. After stimulation with $100 \mu \mathrm{g}$ anti-Ig antibody, $1.7 \times 10^{8} \mathrm{EBV}$ B cells were suspended in $1.5 \mathrm{ml}$ cold Ripa lysis buffer and centrifuged at $10,000 \mathrm{~g}$ for $5 \mathrm{~min}$ (because this assay involved analysis of more cells than did the studies of $\mathrm{Ca}^{2+}$ levels, a greater amount of antibody was used to stimulate the cells). Supernatants were precleared with $0.8 \%$ (wt/vol) Staphlyococcus aureusCowan/strain A (Staph A; Calbiochem, San Diego, CA) for 30 min at $4^{\circ} \mathrm{C}$ and incubated for $1 \mathrm{~h}$ at $4^{\circ} \mathrm{C}$ with $30 \mu \mathrm{l}$ of polyclonal rabbit antihuman PLC- $\gamma 1$ antibody (a kind gift of Dr. T. Pawson, Samuel Lunenfeld Research Institute, Toronto, Ontario). Protein A-Sepharose 4B (Pharmacia, Baie d'Urfé, Quebec), prewashed three times in RIPA lysis buffer, was then added ( $1.3 \% \mathrm{vol} / \mathrm{vol})$ and the samples incubated for another $1 \mathrm{~h}$ at $4^{\circ} \mathrm{C}$. The immune complexes were washed in lysis buffer and pelleted by centrifugation three times at $10,000 \mathrm{~g}$ for $2 \mathrm{~min}$ at $4^{\circ} \mathrm{C}$. The pellets were then boiled for $10 \mathrm{~min}$ and frozen.

Western blotting analysis. EBV B cells $\left(3 \times 10^{6}\right)$ were suspended in $500 \mu \mathrm{l}$ of RPMI and incubated with $20 \mu \mathrm{g}$ anti-Ig. Cells were then pelleted, lysed in Ripa lysis buffer, and boiled for $10 \mathrm{~min}$. These lysates as well as the anti-PLC $\gamma 1$ immunoprecipitates obtained as described above were then subjected to Western blotting as previously described (20). Briefly, the frozen pellets were thawed, centrifuged at $10,000 \mathrm{~g}$ for $5 \mathrm{~min}$, and the proteins were fractionated electrophoretically in polyacrylamide-SDS gels. Proteins were then transferred overnight onto nitrocellulose papers. The unreacted sites on nitrocellulose blots were blocked overnight in a blocking solution of $10 \mathrm{mM}$ Tris, $140 \mathrm{mM}$

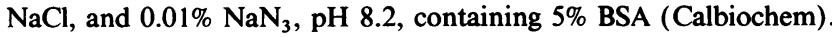
Blots were then incubated overnight with $1 \mu \mathrm{g}$ of monoclonal PY-20 antiphosphotyrosine antibodies (ICN Biomedicals Inc., Costa Mesa, CA) in $4 \mathrm{ml}$ of blocking solution. After washing, the nitrocellulose sheets were incubated for $1 \mathrm{~h}$ with rabbit anti-mouse antibodies (Western Blotting Associates, Mississauga, Ontario, Canada) and then subjected sequentially to two 10 -min washes in $1 \times$ Tris-buffered saline
(TBS), two 15 -min washes in TBS containing $0.5 \%$ Nonidet P-40, and two 10-min washes in TBS. Finally, the filters were incubated for $1 \mathrm{~h}$ with $1 \mu \mathrm{Ci}$ of ${ }^{125}$ I-labeled protein A (Amersham Corp. Oakville, Ontario, Canada) in $4 \mathrm{ml}$ of blocking solution for $1 \mathrm{~h}$, rewashed as before, dried, and exposed to XAR-5 film.

\section{Results}

Proliferative responses to anti-Ig are impaired in WAS B-lymphoblastoid cells. Before analysis of sIg-mediated intracellular signal transduction in WAS EBV B cells, B cell lines derived from WAS patients and healthy controls were compared with regards to their proliferative responses to anti-Ig antibody. As measured by $\left[{ }^{3} \mathrm{H}\right]$ thymidine incorporation, proliferation of normal control EBV B cells increased markedly over the baseline level during the 5-d period after stimulation with anti-Ig antibody (Fig. 1). By contrast, over this same time period, EBV B cells from WAS patients showed little or no change in proliferation rate. Therefore, WAS EBV B cells appear refrac-

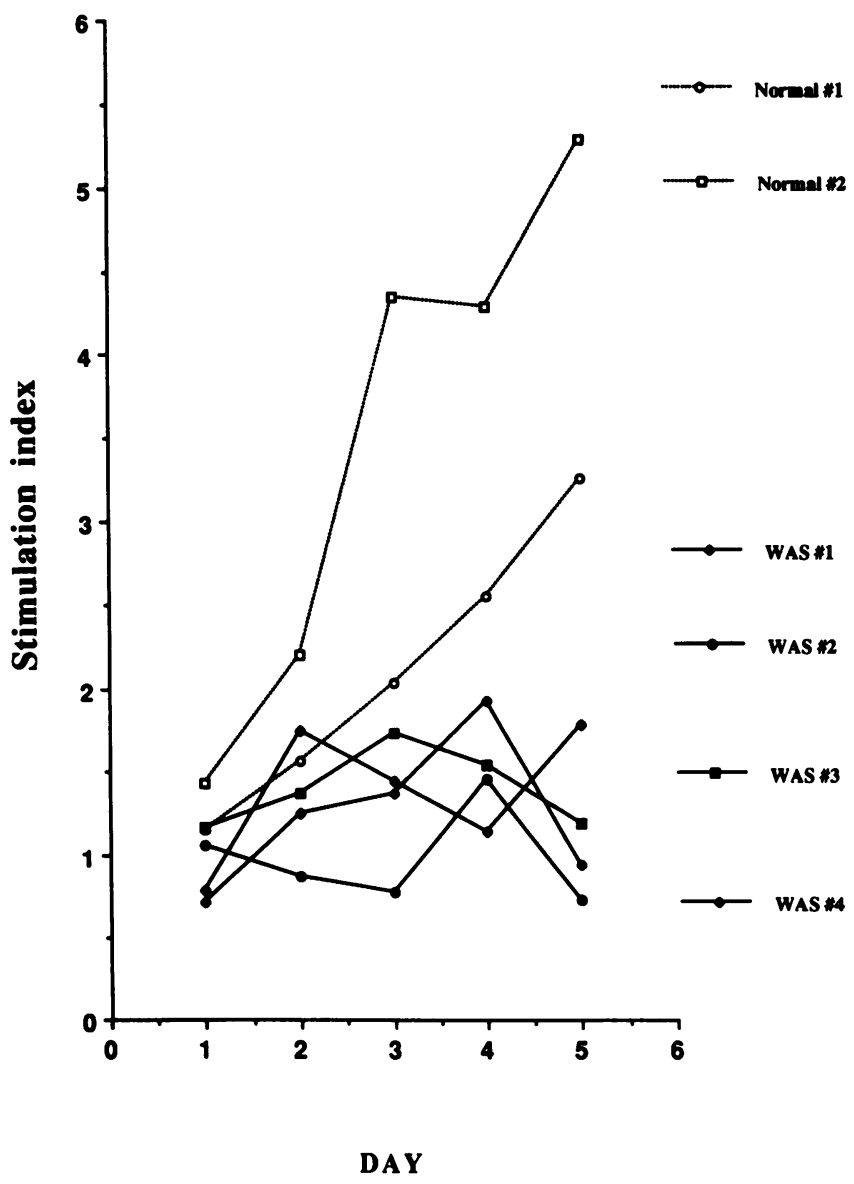

Figure 1. Effect of anti-Ig on proliferation of EBV-transformed B cells from normal individuals and from patients with WAS. Cells cultured in RPMI $+1 \%$ FCS at a density of $10^{4}$ cells/well were stimulated with $5 \mu \mathrm{g} / \mathrm{ml}$ anti-Ig (day 0 ). Proliferation was measured after $1,2,3,4$, and $5 \mathrm{~d}$ of culture by $\left[{ }^{3} \mathrm{H}\right]$ thymidine incorporation. Stimulation indices (see Methods) were calculated using the arithmetic mean values of triplicate cultures (SEs were $<10 \%$ of means). Results of one representative experiment out of two repetitions are shown. The WAS patient cell lines shown here $(1,2$, and 3$)$ are the same three used to derive the data shown in the other figures and correspond to patients 1,5 , and 6 in Table II. 
tory to anti-Ig-induced mitogenesis as is consistent with their manifesting a functional defect similar to that described in $\mathrm{CBA} / \mathrm{N}$ xid $\mathrm{B}$ cells.

Expression of surface immunoglobulin and CD45 is similar on WAS and normal $B$ lymphoblastoid cells. To determine whether the failure of anti-Ig stimulation to induce increased proliferation in WAS EBV B cells reflects altered expression of sIg on these cells, WAS and normal EBV B cell sIg expression was assessed by immunofluorescence staining. As shown in Fig. 2, levels of sIg detected on EBV B cells from WAS patients were comparable to those apparent on cells from control individuals. WAS and normal EBV B cells also showed no differences in levels of sIgM expression (Table I) and in intensity of sIgM staining (data not shown).

Expression of the CD45 tyrosine phosphatase on WAS and normal EBV B cells was also assessed in view of the recognized role of this molecule in regulating the cytoplasmic calcium concentration increases that occur in both $\mathrm{T}$ and $\mathrm{B}$ cells after receptor cross-linking (21). Again, no difference in level of CD45 surface expression (Table I) or staining intensity (data not shown) was apparent between WAS and healthy control EBV B cells.

Anti-Ig-induced intracellular calcium mobilization is markedly decreased or absent in WAS EBV B cells and peripheral blood $B$ cells. The lack of any abnormality in sIg expression on WAS EBV B cells implied that their defective proliferative responses to anti-Ig stimulation reflected a defect in the ability of these cells to transduce signals through their sIg receptors. To determine the nature of this signal transduction defect, the effect of anti-Ig on intracellular $\mathrm{Ca}^{2+}$ mobilization was studied in EBV B cells from WAS patients and healthy controls. Anti-Ig was added at a concentration of $6 \mu \mathrm{g} / \mathrm{ml}$ based on results of preliminary titration studies that indicated that anti-Ig concentrations in the range of $3-5 \mu \mathrm{g} / \mathrm{ml}$ induce maximal calcium responses in EBV B cells. As shown in Fig. $3 \mathrm{~A}$, cross-linking of sIg on B lymphoblastoid cells from normal controls resulted in an immediate increase in $\left[\mathrm{Ca}^{2+}\right]_{i}$. The peak changes in $\left[\mathrm{Ca}^{2+}\right]_{\mathrm{i}}$ ranged between 31 and $92 \mathrm{nM}$ (Table II). After this initial rapid response, the $\left[\mathrm{Ca}^{2+}\right]_{i}$ decreased to a level that was still significantly higher than the basal $\left[\mathrm{Ca}^{2+}\right]_{i}$ and plateaued at this or a slightly increased level for a 15-min time period.

Increased $\left[\mathrm{Ca}^{2+}\right]_{\mathrm{i}}$ after ligand-membrane receptor interaction may reflect uptake of extracellular $\mathrm{Ca}^{2+}$ as well as release of $\mathrm{Ca}^{2+}$ from intracellular stores. To ascertain the source of the biphasic $\mathrm{Ca}^{2+}$ response observed after sIg cross-linking of normal EBV B cells, anti-Ig-stimulated changes in $\left[\mathrm{Ca}^{2+}\right]_{i}$ were also studied using calcium-depleted medium (free $\left[\mathrm{Ca}^{2+}\right]<10$ $\mathrm{nM}$ ), a context that obviates the possibility of extracellular $\mathrm{Ca}^{2+}$ influx but does not affect intracellular $\mathrm{Ca}^{2+}$ release. As shown in Fig. 3, ligation of sIg on EBV B cells in the absence of extracellular $\mathrm{Ca}^{2+}$ was followed by rapid elevation of $\left[\mathrm{Ca}^{2+}\right]_{i}$, comparable to that initially observed using buffers containing normal levels of $\mathrm{Ca}^{2+}$. However, in contrast to the biphasic profile of increased $\left[\mathrm{Ca}^{2+}\right]_{i}$ seen in this latter context, the rise in $\left[\mathrm{Ca}^{2+}\right]_{\mathrm{i}}$ observed under conditions of extracellular $\mathrm{Ca}^{2+}$ depletion was not prolonged, the cytosolic $\mathrm{Ca}^{2+}$ levels returning almost immediately to basal levels. These results suggest that the initial transient rise in $\left[\mathrm{Ca}^{2+}\right]_{\mathrm{i}}$ observed after anti-Ig stimulation of EBV B cells reflects release of intracellular $\mathrm{Ca}^{2+}$ stores, whereas the subsequent prolonged plateauing of the $\mathrm{Ca}^{2+}$ response is due to delayed transmembrane calcium influx.

In contrast to the rapid increase in $\left[\mathrm{Ca}^{2+}\right]_{\mathrm{i}}$ triggered by anti-Ig stimulation of normal EBV B cells, cross-linking of sIg on EBV B cells from WAS patients resulted in a relatively di-

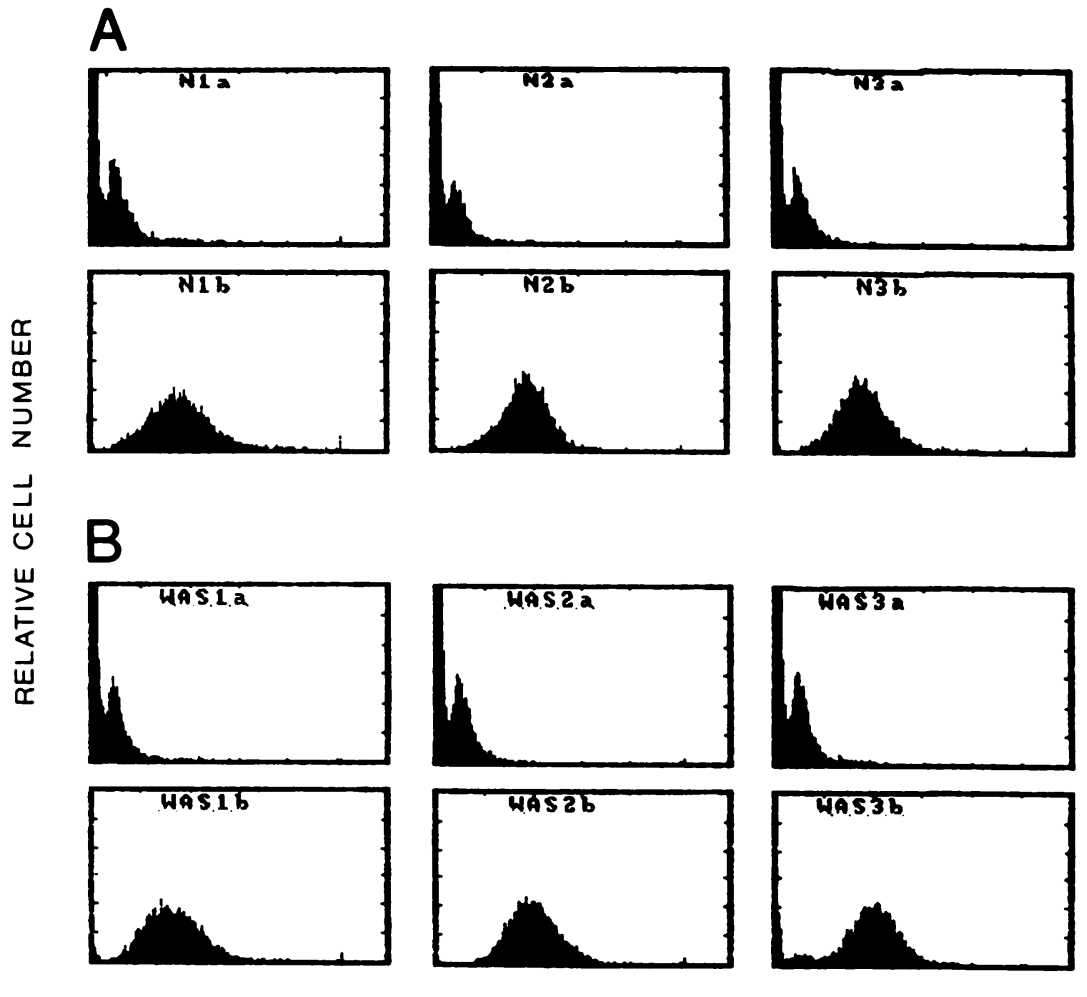

FLUORESCENCE INTENSITY
Figure 2. Surface Ig expression on EBV-transformed B cell lines. EBV-transformed B cells from $(A)$ normal individuals and $(B)$ patients with WAS were stained with either nonspecific rabbit antibody (top) or rabbit anti-human Ig (bottom) followed by a second step reagent (FITC-conjugated goat anti-rabbit antibody) as described in Methods. For each analysis, Ig expression on 10,000 cells was assessed using a flow cytometer. 
Table I. Surface Expression of IgM and CD45 on EBV-transformed B Cells from Normal Individuals and from Patients with WAS

\begin{tabular}{ccc}
\hline \multirow{2}{*}{$\begin{array}{c}\text { Antigen } \\
\text { recognized }\end{array}$} & \multicolumn{2}{c}{ Percent positive cells* } \\
\cline { 2 - 3 } SIgM & Healthy controls & WAS patients \\
\hline CD45 & $32 \pm 17(8)$ & $29 \pm 8(6)$ \\
& $94 \pm 5(4)$ & $97 \pm 1(4)$ \\
\hline
\end{tabular}

* Values are means \pm SD of the percentage of positively stained lymphocytes; value in parentheses is no. of determinations.

minished or absent increase in $\left[\mathrm{Ca}^{2+}\right]_{\mathrm{i}}(\mathrm{Fig} .3 \mathrm{~B})$. The results of repeated assays of anti-Ig-induced intracellular calcium responses in EBV B cell lines derived from nine individual WAS patients are shown in Table II. As may be seen, no measurable change in intracellular $\left[\mathrm{Ca}^{2+}\right]$ was found in three WAS cell
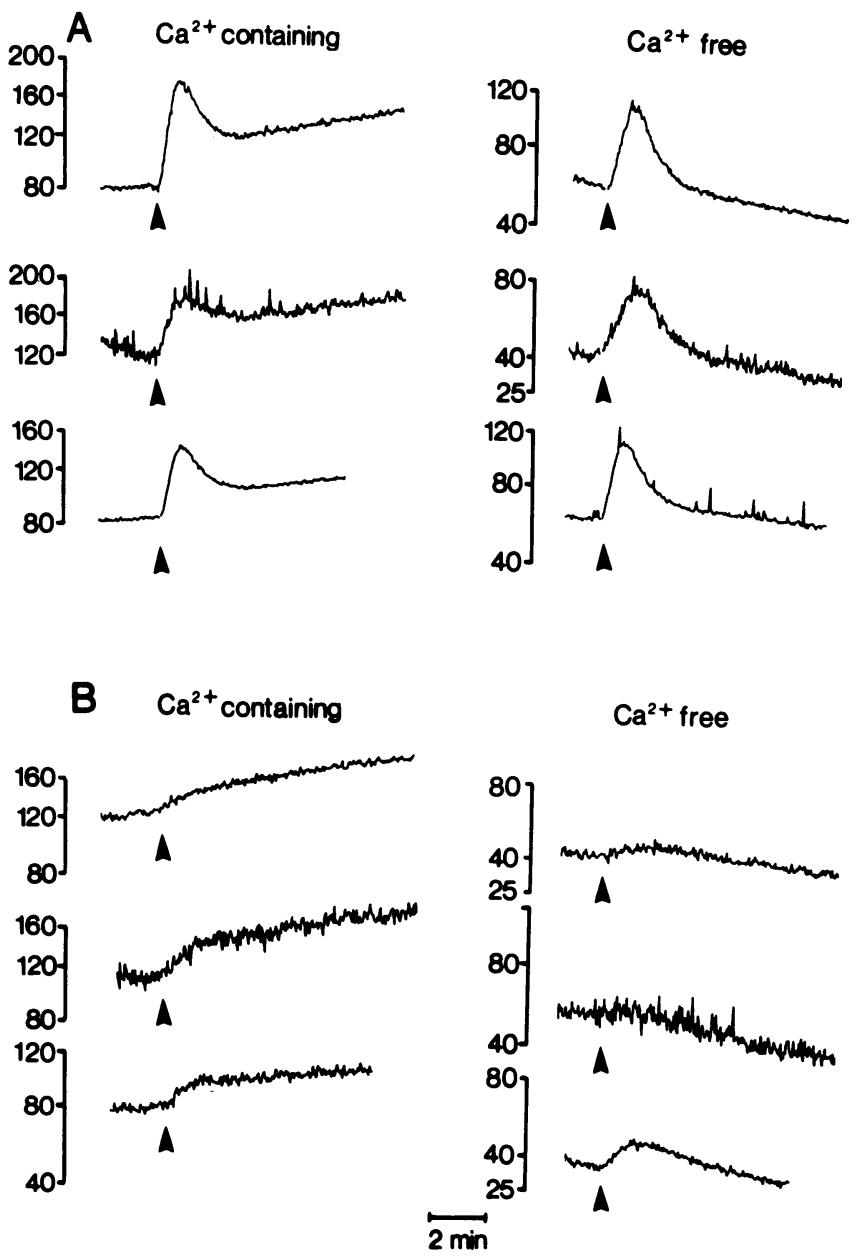

Figure 3. Changes in $\left[\mathrm{Ca}^{2+}\right]_{\mathrm{i}}$ induced by sIg cross-linking. EBV B cell lines from $(A)$ three normal individuals and $(B)$ three representative patients with WAS were loaded with Indo-1 and monitored for changes in $\left[\mathrm{Ca}^{2+}\right]_{\mathrm{i}}$ in response to stimulation with $10 \mu \mathrm{g}$ anti-Ig antibody (arrowhead). As described in Methods, anti-Ig-induced $\left[\mathrm{Ca}^{2+}\right]_{\mathrm{i}}$ changes were followed in $10^{6}$ Indo- 1 loaded cells suspended in $1.7 \mathrm{ml}$ of either $\mathrm{Ca}^{2+}$-containing or nominally $\mathrm{Ca}^{2+}$-free $\left.\left(<10 \mathrm{nM}^{2} \mathrm{Ca}^{2+}\right]\right)$ buffer. Scales at the left of each tracing indicate intracellular free $\left[\mathrm{Ca}^{2+}\right](\mathrm{nM})$.
Table II. Anti-Ig-induced Increases in $\left[\mathrm{Ca}^{2+}\right]_{i}$ in EBV-transformed B Cells from Normal Individuals and from Patients with WAS

\begin{tabular}{lllllllll}
\hline & \multicolumn{8}{c}{ Peak $\Delta\left[\mathrm{Ca}^{2+}\right]_{i}^{*}$} \\
\cline { 2 - 9 } Experiment number & 1 & 2 & 3 & 4 & 5 & 6 & 7 \\
\hline & & \multicolumn{1}{c}{$n M$}
\end{tabular}

Healthy controls

\begin{tabular}{|c|c|c|c|c|c|c|}
\hline 1 & 41 & 59 & 72 & 45 & 60 & \\
\hline 2 & 42 & 64 & 37 & 49 & 50 & \\
\hline 3 & 69 & 42 & 75 & - & - & \\
\hline 4 & 40 & 31 & - & - & - & \\
\hline 5 & 60 & 82 & - & - & - & \\
\hline 6 & 53 & 64 & - & - & - & \\
\hline 7 & 45 & 53 & - & - & - & \\
\hline 8 & 64 & - & - & - & 一 & \\
\hline 9 & 40 & - & - & - & - & \\
\hline 10 & 92 & - & - & - & - & \\
\hline 11 & 88 & - & - & - & - & \\
\hline 12 & 46 & - & - & - & - & \\
\hline 13 & 50 & - & - & - & 一 & \\
\hline 14 & 84 & - & - & - & - & \\
\hline 15 & 90 & - & - & - & - & \\
\hline 16 & 70 & - & - & - & 一 & \\
\hline Mean $\pm \operatorname{SD}(n=30)$ & $58 \pm 17$ & & & & & \\
\hline Range & $31-92$ & & & & & \\
\hline \multicolumn{7}{|l|}{ AS patients } \\
\hline 1 & 20 & 20 & 14 & 8 & 0 & 0 \\
\hline 2 & 19 & 7 & 0 & 15 & - & - \\
\hline 3 & 0 & 0 & 0 & - & - & - \\
\hline 4 & 20 & 24 & 11 & - & - & - \\
\hline 5 & 24 & 15 & 10 & - & - & - \\
\hline 6 & 24 & 0 & - & - & - & - \\
\hline 7 & 0 & 0 & - & - & - & - \\
\hline 8 & 18 & 11 & - & - & - & - \\
\hline 9 & 0 & - & - & - & 一 & - \\
\hline Mean \pm SD $(n=27)$ & $10 \pm 9$ & & & & & \\
\hline Range & $0-24$ & & & & & \\
\hline
\end{tabular}

* Values represent highest levels of cytosolic free $\mathrm{Ca}^{2+}$ measured in Indo-1-loaded EBV B cells $\left(10^{6}\right.$ cells in $\left.1.7 \mathrm{ml}\right)$ within 3 min after stimulation with $10 \mu \mathrm{g}$ anti-Ig antibody. Each data point represents the result of an independent experiment. $n$ is the total number of independent experiments.

lines consistently, and on at least one occasion in four others. In WAS B cell lines that did show increased $\left[\mathrm{Ca}^{2+}\right]_{\mathrm{i}}$ in response to sIg ligation, the $\left[\mathrm{Ca}^{2+}\right]_{\mathrm{i}}$ did not peak immediately after stimulation but instead rose slowly over the following 15 -min period. This latter profile of $\mathrm{Ca}^{2+}$ mobilization is illustrated in Fig. $3 B$ in which changes in $\left[\mathrm{Ca}^{2+}\right]_{i}$ are shown for the three WAS EBV B cell lines manifesting the most substantial increases in $\left[\mathrm{Ca}^{2+}\right]_{\mathrm{i}}$ in response to sIg ligation. However, as is evident from the data included in Table II, maximal intracellular $\mathrm{Ca}^{2+}$ concentrations attained after sIg cross-linking were significantly less in 9 consecutively studied EBV B cell lines of WAS patients compared with those observed in 16 consecutively studied B cell lines from healthy controls $(P<0.001$, Student's $t$ test $)$. Although the absolute $\Delta\left[\mathrm{Ca}^{2+}\right]_{\mathrm{i}}$ detected in given cell lines varied somewhat in repeat assays, the distinc- 
tion between WAS and normal responses to anti-Ig was consistently apparent such that even the highest $\Delta\left[\mathrm{Ca}^{2+}\right]_{\mathrm{i}}(24 \mathrm{nM})$ observed among the WAS cell lines was lower than the lowest $\Delta\left[\mathrm{Ca}^{2+}\right]_{\mathrm{i}}$ detected in the control lines ( $31 \mathrm{nM}$; Table II). Furthermore, in contrast to normal EBV B cells, the WAS EBV B cell $\mathrm{Ca}^{2+}$ response to sIg ligation was either entirely abrogated or markedly diminished in the absence of extracellular $\mathrm{Ca}^{2+}$ (Fig. $3 \mathrm{~B}$ ). Therefore, extracellular $\mathrm{Ca}^{2+}$ influx rather than intracellular $\mathrm{Ca}^{2+}$ release appears largely responsible for the increases in $\left[\mathrm{Ca}^{2+}\right]_{\mathrm{i}}$ observed in some WAS patient $\mathrm{B}$ cells after sIg cross-linking.

sIg-induced $\mathrm{Ca}^{2+}$ responses were also assessed in freshly isolated peripheral blood lymphocytes obtained from three affected boys (WAS patients 1, 2, and 3) and three controls. As was observed in the EBV B cell lines, peak changes in $\left[\mathrm{Ca}^{2+}\right]_{i}$ were consistently lower in WAS compared with control antiIg-stimulated cells (Table III). This finding does not appear related to a relative reduction in peripheral blood $B$ cell number in WAS patients, since the percentage of circulation B cells, as defined by staining with the pan-B-cell marker, CD20, was comparable between the patients and controls. (Table III). Furthermore, similar results were obtained by analysis of $\mathrm{Ca}^{2+}$ responses in sorted $\mathrm{CD}_{2} 0^{+}$peripheral blood mononuclear cells. As is evident from the representative example shown in Fig. 4, anti-Ig-stimulated CD20 ${ }^{+} \mathrm{B}$ cells from WAS patients did not manifest either the rapid rise or the magnitude of $\Delta\left[\mathrm{Ca}^{2+}\right]_{\mathrm{i}}$ apparent in similarly treated control CD20 ${ }^{+}$cells.

Taken together these results reveal that the ability to mobilize $\mathrm{Ca}^{2+}$ from intracellular stores in response to $\mathrm{sIg}$ ligation is either lacking or markedly reduced in WAS patient compared with normal B lymphocytes. Accordingly, it appears likely that at least some facets of B cell dysfunction in WAS patients may reflect abnormalities in signal transduction, and in particular, in the signaling pathways that elicit intracellular calcium mobilization. Lastly, it should be noted that neither the profile nor level of WAS EBV B cell intracellular $\mathrm{Ca}^{2+}$ mobilization was

Table III. Surface Expression of CD20 and Anti-Ig-induced Increases in $\left[\mathrm{Ca}^{2+}\right]_{i}$ in Peripheral Blood Cells from Normal Individuals and WAS Patients

\begin{tabular}{lcc}
\hline & Percent $\mathrm{CD} 20^{+}$peripheral blood cells & Peak $\Delta\left[\mathrm{Ca}^{2+}\right]_{i}^{*}$ \\
\hline Healthy controls & & $n M$ \\
1 & & \\
2 & 5 & 75 \\
3 & 6 & 75 \\
Mean \pm SD & 12 & 48 \\
Range & $7.7 \pm 3.8$ & $66.0 \pm 15.6$ \\
WAS patients & $6-12$ & $48-75$ \\
1 & & \\
2 & 4 & 18 \\
3 & 2 & 5 \\
Mean \pm SD & 18 & 19 \\
Range & $8.0 \pm 8.7$ & $14.0 \pm 7.8$ \\
& $2-18$ & $5-19$ \\
\hline
\end{tabular}

* Values represent highest levels of cytosolic free $\mathrm{Ca}^{2+}$ measured in Indo-1-loaded peripheral blood mononuclear cells $\left(10^{6}\right.$ cells in 1.7 $\mathrm{ml}$ ) within $3 \mathrm{~min}$ after stimulation with $10 \mu \mathrm{g}$ anti-Ig antibody.

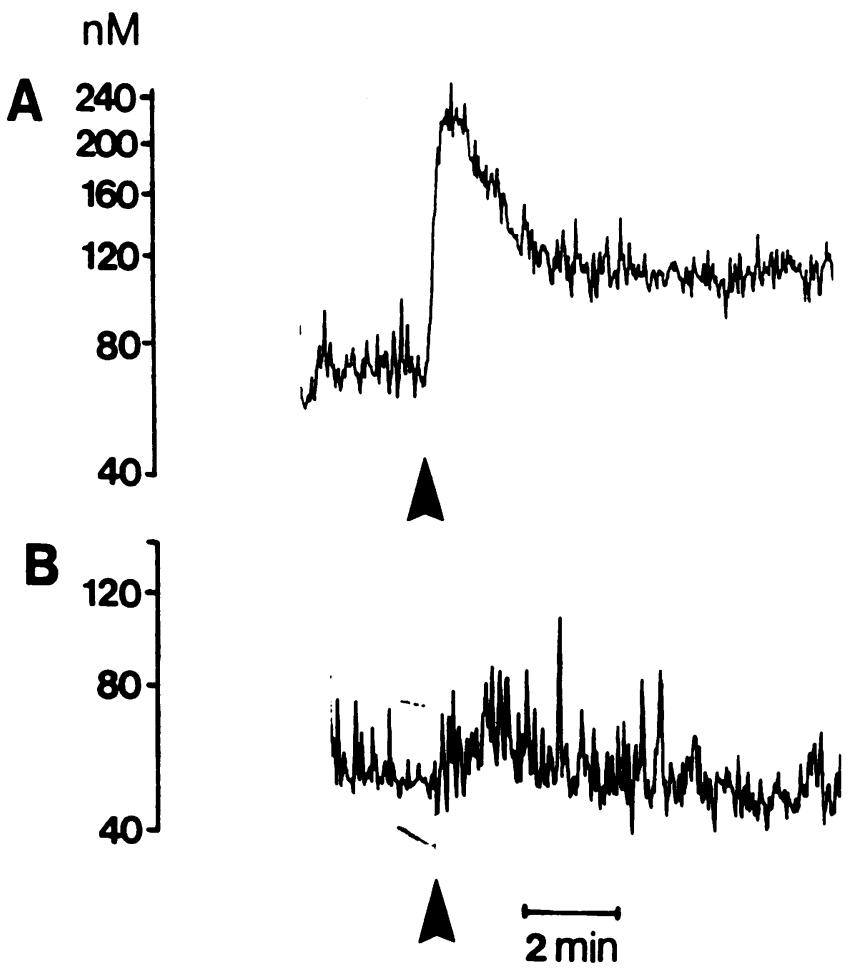

Figure 4. Changes in $\left[\mathrm{Ca}^{2+}\right]_{\mathrm{i}}$ induced by ligation of sIg on freshly isolated $\mathrm{CD} 20^{+} \mathrm{B}$ cells. Peripheral blood mononuclear cells from a normal individual $(A)$ and a WAS patient $(B)$ were stained with FITC-conjugated anti-CD20 antibody and the CD20 ${ }^{+}$cells collected by sorting on a flow cytometer. As detailed in Methods, the selected cells $\left(90 \% \mathrm{CD}^{2} 0^{+}\right)$were loaded with Indo- 1 and monitored for changes in $\left[\mathrm{Ca}^{2+}\right]_{\mathrm{i}}$ in response to stimulation with $10 \mu \mathrm{g}$ anti-Ig antibody (arrowhead). The data shown are representative of two independent determinations.

altered by the use of higher anti-Ig dose or anti-Ig cross-linked by rabbit anti-mouse antibody (data not shown).

Anti-Ig-induced increases in phosphatidylinositol hydrolysis are diminished in WAS compared with control EBV B cells. In view of the correlation between anti-Ig-induced intracellular $\mathrm{Ca}^{2+}$ release and PLC-mediated triggering of phosphoinositide hydrolysis, the induction of inositol phosphate production after sIg ligation was measured in $\left[{ }^{3} \mathrm{H}\right]$ myoinositol-loaded EBV B cells from three WAS patients and three controls. As shown in Table IV, release of inositol phosphates was evident in anti-Ig-stimulated WAS EBV B cells but was reduced by about $50 \%$ in these cells compared with the levels observed in similarly treated control cells. As $>95 \%$ of the $\left[{ }^{3} \mathrm{H}\right]$ inositol incorporated into inositol phosphates after cellular activation appear to be derived from phosphatidylinositol $(22,23)$, this result suggests that a defect in anti-Ig-induced PLC-dependent phosphoinositide hydrolysis occurs in WAS EBV B cells and may account for their diminished degree of intracellular $\mathrm{Ca}^{2+}$ release in response to sIg ligation.

Tyrosine phosphorylation is not increased by cross-linking sIg on WAS EBV B cells. In previous studies we have shown that induction of protein tyrosine phosphorylation is a prerequisite for the mobilization of $\mathrm{Ca}^{2+}$ from intracellular stores after sIg ligation in B cells (13). This observation appears to reflect a requirement for tyrosine phosphorylation in the activation of PLC- $\gamma$ and suggests that protein tyrosine phosphory- 
Table IV. Induction of Inositol Phosphate Release by Ligation of sIg on WAS and Control EBV B cells

\begin{tabular}{lcc}
\hline & \multicolumn{2}{c}{ Increase in $\left.{ }^{3} \mathrm{H}\right]$ inositol phosphates } \\
\cline { 2 - 3 } & Fold increase $^{\ddagger}$ & $\begin{array}{r}\text { Baseline levels of inositol } \\
\text { phosphate formation }\end{array}$ \\
\hline Healthy controls & & $c p m$ \\
1 & 3.64 & \\
2 & 1.87 & $(85)$ \\
3 & 1.86 & $(99)$ \\
Mean \pm SD & $2.46 \pm 1.02$ & $(156)$ \\
Range & $1.86-3.64$ & \\
WAS patients & & \\
1 & 1.18 & $(60)$ \\
2 & 1.10 & $(60)$ \\
3 & 0.80 & $(389)$ \\
Mean \pm SD & $1.03 \pm 0.20$ & \\
Range & $0.80-1.18$ & \\
\end{tabular}

* $\left[{ }^{3} \mathrm{H}\right]$ inositol phosphate formation was measured in $5 \times 10^{7}$ [ ${ }^{3} \mathrm{H}$ ]myoinositol-loaded EBV B cells 3 min after stimulation with 20 $\mu \mathrm{g}$ anti-Ig antibody. ${ }^{\ddagger}$ Results are expressed as $\left[{ }^{3} \mathrm{H}\right]$ inositol phosphate formation in anti-Ig-treated cells $/\left[{ }^{3} \mathrm{H}\right]$ inositol phosphate formation in untreated cells; each value represents the mean of determinations done on duplicate samples in six independent experiments. ${ }^{\S} \mathrm{Num}-$ bers in parentheses represent the levels of inositol phosphate incorporation in untreated cells.

lation is induced before increases in $\left[\mathrm{Ca}^{2+}\right]_{\mathrm{i}}$ in anti-Ig-stimulated B cells. Accordingly, we next examined the possible relevance of a defect in tyrosine phosphorylation to the differences in sIg-stimulated intracellular $\mathrm{Ca}^{2+}$ release apparent between EBV B cells of WAS patients and normal individuals.

In preliminary studies of EBV B cells from normal individuals, we established that the degree of intracellular protein tyrosine phosphorylation begins to increase within seconds after ligation of $\mathrm{sIg}$, peaks in $\sim 3 \mathrm{~min}$, and declines thereafter (data not shown). Furthermore, as has been previously observed in nontransformed B cells, anti-Ig-provoked increases in tyrosine phosphorylation occurred in parallel or before the initial rise in cytosolic $\left[\mathrm{Ca}^{2+}\right]$, a finding that is consistent with the contention that tyrosine phosphorylation represents a more proximal signaling event than intracellular $\mathrm{Ca}^{2+}$ release. Interestingly, the plateau phase of increased $\left[\mathrm{Ca}^{2+}\right]_{i}$ that persists after anti-Ig stimulation occurs despite the decrease in the amount of protein tyrosine phosphorylation.

Based on these findings, tyrosine phosphorylation of WAS and normal EBV B cell proteins was assayed $3 \mathrm{~min}$ after treatment of these cells with anti-Ig antibody. As illustrated by the representative examples shown in Fig. 5, sIg ligation of EBV B cells from five normal individuals was consistently associated with increased tyrosine phosphorylation of proteins with molecular masses of 110,55 , and $34 \mathrm{kD}$. Tyrosine phosphorylation of $85-$ and $39-\mathrm{kD}$ proteins was also observed in some of the normal cell lines. Among these protein bands, the anti-Ig-induced increase in tyrosine phosphorylation was most obvious in relation to the $34-\mathrm{kD}$ species, a band that was almost not detectable before sIg cross-linking. As noted in relation to the total protein tyrosine phosphorylation, maximal phosphorylation of this $34-\mathrm{kD}$ band occurred at $3 \mathrm{~min}$ after sIg ligation and declined to baseline level within $10 \mathrm{~min}$ (data not shown).

In contrast to normal EBV B cell lines, cross-linking of sIg on EBV B cells from five WAS patients failed to increase tyrosine phosphorylation of any protein species. As indicated by the three examples shown in Fig. 5 (which represent the same WAS cell lines used to derive data shown in Fig. $3 B$ ) and confirmed by the results of laser densitometry, the anti-Ig-induced increases in tyrosine phosphorylation of 110-, 55-, and 34-kD proteins that were detected in normal EBV B cells were not apparent in any WAS EBV B cell line. Moreover, increases in tyrosine phosphorylation of these molecules were not observed even after prolonged incubation (up to $60 \mathrm{~min}$ ) of the WAS cells with anti-Ig antibody (data not shown). These results indicate that anti-Ig-induced increases in tyrosine phosphorylation are markedly diminished in WAS compared with normal EBV B cells and may even be absent in cells from some of these patients.

To specifically determine whether surface Ig ligation induces tyrosine phosphorylation of PLC in WAS B cells, phosphorylation of the $\gamma 1$ isozyme of PLC was assessed in WAS and control EBV B cells by immunoprecipitation and Western blot analysis. For analysis of tyrosine phosphorylation of PLC- $\gamma 1$,
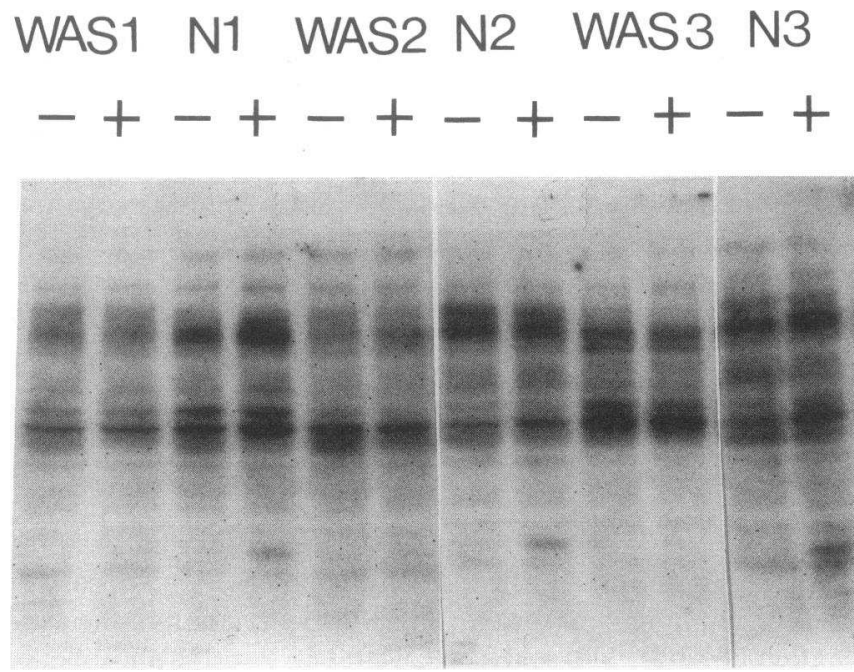

Figure 5. Immunoblots showing the effect of sIg cross-linking on protein tyrosine phosphorylation in EBV B cells. EBV-transformed B cells $\left(3 \times 10^{6}\right)$ from three normal individuals and from three patients with WAS (same as those presented in Figs. $1-3)$ were cultured in serum-free medium for 24 $\mathrm{h}$ and then incubated with $(+)$ or without $(-) 20$ $\mu \mathrm{g}$ anti-Ig antibody. Cells were lysed in Ripa buffer and centrifuged, and the supernatant proteins were electrophoretically separated in SDS-polyacrylamide gels. After transfer to nitrocellulose, proteins were probed with a monoclonal antibody to phosphotyrosine. The migration positions of prestained molecular mass standards (in $\mathrm{kD}$ ) are shown on the right. The arrows indicate protein bands showing net increases in tyrosine phosphorylation after sIg cross-linking. Results of one representative experiment out of three are shown for each individual. 
cells were lysed 3 min after anti-Ig stimulation and the lysate proteins were immunoprecipitated with a rabbit anti-PLC- $\gamma 1$ antisera, resolved by SDS-PAGE, transferred to nitrocellulose, and probed with anti-phosphotyrosine antibody. As is evident from the representative example shown in Fig. 6, tyrosine phosphorylated PLC- $\gamma 1$ is essentially undetectable in unstimulated control or WAS EBV B cells but is apparent in the control EBV B cells after anti-Ig treatment. By contrast, tyrosine phosphorylated PLC- $\gamma 1$ was not detected in anti-Ig-stimulated WAS EBV B cells. This latter observation cannot be ascribed to differences in PLC- $\gamma 1$ expression in WAS compared with control cells, as the results of immunoblot and Northern analyses indicated that levels of PLC- $\gamma 1 \mathrm{mRNA}$ and protein, respectively, are similar in WAS and control EBV B cell lines (data not shown). Together these results suggest that induction of tyrosine phosphorylation on PLC- $\gamma 1$, a key event in the activation of this enzyme after sIg ligation, is impaired in WAS EBV $B$ cells, as is consistent with the finding that anti-Ig-induced increases in intracellular protein tyrosine phosphorylation and $\mathrm{Ca}^{2+}$ mobilization are diminished in these cells compared with EBV B cells from controls.

\section{Discussion}

The molecular basis for the severe immune deficiency expressed by patients with WAS remains undefined, but recent data suggest that $B$ cell dysfunction occurs in these patients and resembles that described in $\mathrm{X}$ chromosome-linked immunodeficient CBA/N mice. Accordingly, the reported association of the xid mutation with impaired anti-Ig-induced B cell proliferation and intracellular $\mathrm{Ca}^{2+}$ mobilization prompted us to investigate signaling via sIg on B cells from WAS patients. The results of the studies reported here reveal that EBV-trans-
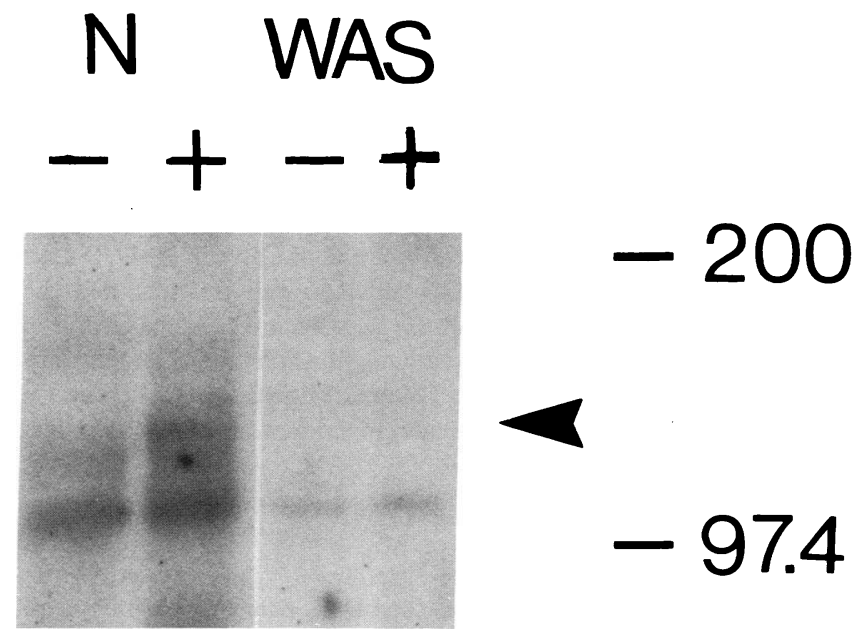

Figure 6. Immunoblot showing the effect of sIg cross-linking on the tyrosine phosphorylation of PLC- $\gamma 1$ in EBV B cells. Cell lysates were prepared from $1.7 \times 10^{8}$ anti-Ig antibody-stimulated $(+)$ or unstimulated (-) EBV B cells and were incubated with PLC- $\gamma 1$-specific antiserum followed by Protein A-Sepharose 4B. The immunoprecipitated proteins were eluted, electrophoresed through SDS-PAGE, transferred to nitrocellulose, and probed with antiphosphotyrosine antibody. The migration positions of prestained molecular mass standards (in $\mathrm{kD}$ ) are shown on the right. The arrow indicates the position of tyrosine-phosphorylated PLC- $\gamma 1$. formed B cells from WAS patients do not manifest increased proliferation in response to sIg ligation, despite their expression of sIg at levels comparable to those found on control EBV B cells. In addition, our findings indicate that several key sequelae of sIg ligation, i.e., increase in protein tyrosine phosphorylation and most notably PLC- $\gamma 1$ tyrosine phosphorylation, production of inositol phosphates, and induction of $\mathrm{Ca}^{2+}$ release from intracellular stores, are markedly diminished in WAS compared with normal control EBV B cells. These data provide further evidence of an intrinsic defect in WAS B cells and suggest that at least some of the immune abnormalities found in these patients may reflect impaired lymphocyte competency to transduce activation signals.

Because of the difficulties inherent to obtaining sufficient numbers of fresh B cells from young children, and in particular from frequently ill and anemic WAS children, most of the analyses of sIg-mediated signaling described in this paper were carried out using EBV-transformed B cell lines. Although we cannot be certain of the extent to which the functional and phenotypic properties of these immortalized cells are representative of those manifested by nontransformed B cells in vivo, the finding of impaired intracellular $\mathrm{Ca}^{2+}$ release in freshly isolated $\mathrm{B}\left(\mathrm{CD} 20^{+}\right)$cells from two WAS patients suggests strongly that WAS B cells are defective with regards to signal transduction. This contention is supported by the distinct and consistent differences apparent between WAS and normal EBV B cells in relation to several of the other biochemical sequelae of sIg ligation, including tyrosine phosphorylation of PLC- $\gamma 1$ and phosphatidylinositol hydrolysis.

Accordingly, it appears that EBV-transformed B cells provide a valuable model system for studying the functional characteristics of WAS and perhaps other immunodeficient patient $B$ cells. In addition, as has been previously found in other studies (24), our data indicate that immortalized cell lines can be successfully exploited for characterization of cell signaling mechanisms. For example, the results of our studies on WAS EBV B cells indicate that transmembrane uptake of extracellular $\mathrm{Ca}^{2+}$ during lymphocyte activation can occur in the absence of intracellular $\mathrm{Ca}^{2+}$ mobilization or detectable protein tyrosine phosphorylation. Therefore, in contrast to data garnered using other cell types, including $\mathrm{T}$ cells, the results presented here suggest that extracellular $\mathrm{Ca}^{2+}$ influx does not depend on the tyrosine phosphorylation and activation of PLC- $\gamma$ or on the generation of $\mathrm{IP}_{3}, \mathrm{IP}_{4}$, or other inositol phosphates produced consequent to PLC- $\gamma$ activation.

Although the capacity of sIg receptors to transduce activation signals in B cells is well established, the mechanisms whereby they do so have not been clearly elucidated. Neither sIgM nor SIgD, the predominant sIg isotypes on mature B cells, have sufficient cytoplasmic structure to interact directly with the other intracellular molecules, such as $G$ proteins and tyrosine kinases, that mediate signal transduction $(25,26)$. The resolution of this dilemma, however, appears to be forthcoming as the result of the recent identification of several sIg-associated glycoproteins that do have intracellular domain structure suitable for delivery of activation signals (25-29). Among these newly identified molecules are two sIgM-associated proteins, designated as IgM- $\alpha$ and IgM- $\beta$, which have molecular masses of 34 and $39 \mathrm{kD}$, respectively $(25,26)$. These proteins, which represent the products of the mb-1 (IgM- $\alpha$ ) and B29 $($ IgM- $\beta$ ) genes, comprise a disulfide-linked heterodimer that associates with sIgM to form a sIgM receptor complex. Al- 
though the functions of these molecules are not fully understood, recent data showing their inducible tyrosine phosphorylation after sIg ligation (30) imply that these proteins are involved in signal transduction and hence may be relevant to defective signaling in WAS B cells. As expression of IgM- $\alpha$ seems to be required for the transport of IgM to the cell surface (28) and levels of sIgM expression appear comparable on WAS and normal EBV B cells, it seems unlikely that the hyporesponsiveness of WAS cells to anti-Ig relates to insufficient quantity of IgM- $\alpha$ protein. Furthermore, a constitutively tyrosine-phosphorylated protein with a size comparable to that of IgM- $\alpha$ ( 34 $\mathrm{kD}$ ) was detected, albeit at low levels, in both the WAS and normal EBV B cells studied here. Therefore, in contrast to $\mathrm{CBA} / \mathrm{N}$ mice, in which impaired membrane expression of a sIg-associated protein has been described (31), altered signaling in WAS B cells appears unrelated to IgM- $\alpha$ expression per se. However, after sIg ligation, the WAS EBV B cells failed to manifest the increased tyrosine phosphorylation of either the 34-kD or several other protein species that was observed in anti-Ig-treated EBV B cells from controls.

In view of the putative role for IgM- $\alpha$ in signal transduction, this latter finding raises the possibility that failure to phosphorylate IgM- $\alpha$ may be directly responsible for reduced activation of PLC and $\mathrm{Ca}^{2+}$ release in WAS EBV B cells. In B cells, coupling of sIg to the phosphoinositide signaling pathway is associated with and appears to require activation of G-proteins (32-35). Accordingly, it is possible that defective generation of tyrosine-phosphorylated IgM- $\alpha$ in anti-Ig-stimulated WAS B cells interrupts transduction of $\mathrm{Ca}^{2+}$-mobilizing signals by interfering with an IgM- $\alpha-\mathrm{G}$-protein interaction required for PLC activation. However, our data also reveal anti-Ig-stimulated WAS EBV B cells to be defective with regards to the generation of tyrosine phosphorylated PLC- $\gamma 1$. Therefore, it is also possible and perhaps more likely that altered $\mathrm{Ca}^{2+}$ release after sIg cross-linking in the WAS cells is, at least in part, a direct consequence of defective tyrosine phosphorylation of PLC isozymes, a phenomenon that normally accompanies and is considered necessary for sIg-induced activation of these enzymes and stimulation of phosphatidylinositol hydrolysis (24). In this context, the link between G-proteins and PLC activation may not be through IgM- $\alpha$, but instead, as we have previously shown in neutrophils (36), may involve G-protein modulation of a tyrosine kinase or phosphatase activity required for phosphorylation and activation of PLC. One other point worth noting with regards to anti-Ig-induced tyrosine phosphorylation of PLC is that tyrosine phosphorylated PLC$\gamma 1$, while clearly identifiable in anti-Ig-treated control EBV B cells (Fig. 6), was not detected in antiphosphotyrosine antibody immunoblots of total cell lysates (Fig. 5). This finding suggests that among the various isozymes of PLC, the $\gamma 1$ form of the enzyme does not represent one of the major substrates for anti-Ig-induced tyrosine phosphorylation.

Studies of the signaling events initiated by engagement of the antigen receptor on $T$ cells have revealed that transduction of $\mathrm{Ca}^{2+}$-mobilizing signals in these cells requires their expression of a membrane tyrosine phosphatase, $\operatorname{CD} 45(37,38)$. In addition, the pattern of $\mathrm{Ca}^{2+}$ mobilization as well as cellular activation and proliferation induced by cross-linking of the antigen receptors on either $\mathrm{B}$ or $\mathrm{T}$ lymphocytes is markedly altered in the context of coincident cross-linking of CD45 (21). Although these data suggest a role for CD45 in sIg-mediated signal transduction, our finding of similar levels of membrane
CD45 expression by WAS and control EBV B cells indicates that defective signal transduction in the WAS cells cannot be ascribed to the absence or reduced expression of this phosphatase. These results do not, however, preclude the possibility that CD45 may be functionally defective in WAS B lymphocytes.

In summary, the data reported here indicate that WAS EBV B cells are defective with regards to their ability to proliferate and to transduce $\mathrm{Ca}^{2+}$-mobilizing and tyrosine phosphorylation signals in response to sIg cross-linking. The results suggest that disruption of early signaling events in these cells reflects a defect at a point upstream of tyrosine phosphorylation of PLC, possibly related to dysfunction of tyrosine kinases such as the lyn or blk kinases that have recently been implicated in sIgM-triggered signal transduction $(37,38)$. As anti-Ig-induced cross-linking of sIg is thought to represent a model for the intracellular events triggered by $B$ cell stimulation with $T$ independent antigens (39), our findings suggest that aberrant transmembrane signal transduction may account for the nonresponsiveness of WAS patient $B$ cells to certain T independent antigens and may also underlie or contribute to other abnormalities of WAS B cell function. Although the extent to which cell signaling is altered in other hemopoietic lineages of WAS patients remains to be determined, defective signal transduction provides an attractive and plausible explanation for the impaired $\mathrm{T}$ cell and platelet activation observed in these patients and may also underlie other facets of WAS cellular dysfunction. Thus, although it is unclear whether impaired B cell signal transduction in WAS represents a direct or indirect consequence of the primary gene defect, continued investigation of the process whereby signal transduction is altered in WAS EBV B cells should provide valuable insights into the molecular basis for expression of the WAS phenotype. Analysis of the structural elements and level of the signal abnormalities that interfere with delivery of normal sIg-mediated activation signals in WAS B cells also represents a promising avenue toward delineating the nature and sequence of the molecular interactions that mediate lymphocyte signal transduction.

\section{Acknowledgments}

This work was supported by grants from the Medical Research Council of Canada and the National Cancer Institute of Canada. H.-U. Simon is supported by the Samuel Lunenfeld Research Institute and the Deutsche Forschungsgemeinschaft. G. B. Mills is a Medical Research Council of Canada Scientist and a McLaughlin Scientist. K. A. Siminovitch is a Career Scientist of the Ontario Ministry of Health and a recipient of a Canadian Life and Health Insurance Association Medical Scholarship.

\section{References}

1. Aldrich, R. A., A. G. I. Steinberg, and D. C. Campbell. 1954. Pedigree demonstrating a sex-linked recessive condition characterized by draining ears, eczematoid dermatitis and bloody diarrhea. Paediatrics. 13:133-138.

2. Spitler, L. E., A. S. Levin, D. P. Stites, H. H. Fudenberg, and H. Huber 1975. The Wiskott-Aldrich syndrome: immunologic studies in nine patients and selected family members. Cell. Immunol. 19:201-218.

3. Oppenheim, J. J., R. M. Blaese, and T. A. Waldmann. 1970. Defective lymphocyte transformation and delayed hypersensitivity in Wiskott-Aldrich syndrome. J. Immunol. 104:835-844.

4. Cooper, M. D., H. P. Chase, J. T. Lowman, W. Krivit, and R. A. Good. 1968. The Wiskott-Aldrich syndrome: an immunologic deficiency disease involving the afferent limb of immunity. Am. J. Med. 44:499-513.

5. Morio, T., K. Takase, H. Okawa, M. Oguchi, M. Kanbara, F. Hirumi, K. Yoshino, T. Kaneko, S. Asamura, T. Inoue, et al. 1989. The increase of non- 
MHC-restricted cytotoxic cells (gamma/delta-TCR-bearing T cells or NK cells) and the abnormal differentiation of B cells in Wiskott-Aldrich syndrome. Clin. Immunol. Immunopathol. 52:270-290.

6. Prchal, J. T., A. J. Carol, J. F. Prchal, W. McCrist, H. W. Skalka, W. J. Gealy, and A. Malluh. 1980. Wiskott-Aldrich syndrome: cellular impairments and their implications for carrier detection. Blood. 56:1048-1052.

7. Greer, W. L., P. C. Kwong, M. Peacocke, P. Ip, L. A. Rubin, and K. A. Siminovitch. 1989. X-chromosome inactivation in the Wiskott-Aldrich syndrome: a marker for detection of the carrier state and identification of cell lineages expressing the gene defect. Genomics. 4:60-67.

8. Higgins, E. A., K. A. Siminovitch, D. Zhuang, I. Brockhausen, and J. W. Dennis. 1991. Aberrant O-linked oligosaccharide biosynthesis in lymphocytes and platelets from patients with the Wiskott-Aldrich syndrome. J. Biol. Chem. 266:6280-6290.

9. Golding, B., A. V. Muchmore, and R. M. Blaese. 1984. Newborn and Wiskott-Aldrich patient $B$ cells can be activated by TNP-Brucella abortus: evidence that TNP-Brucella abortus behaves as a T-independent type 1 antigen in humans. J. Immunol. 133:2966-2971.

10. Scher, I. 1982. The CBA/N mouse strain: an experimental model illustrating the influence of the X-chromosome on immunity. Adv. Immunology. 33:1-71.

11. Gold, M. R., D. A. Law, and A. L. DeFranco. 1990. Stimulation of protein tyrosine phosphorylation by the B-lymphocyte antigen receptor. Nature (Lond.). 345:810-813.

12. Campbell, M.-A., and B. M. Sefton. 1990. Protein tyrosine phosphorylation is induced in murine $B$ lymphocytes in response to stimulation with anti-immunoglobulin. EMBO (Eur. Mol. Biol. Organ.) J. 9:2125-2131.

13. Padeh, S., A. Levitzki, A. Gazit, G. B. Mills, and C. M. Roifman. 1991. Activation of phospholipase $C$ in human B cells is dependent on tyrosine phosphorylation. J. Clin. Invest. 87:1114-1118.

14. Chein, M. M., and R. F. Ashman. 1983. Phospholipid synthesis by activated human B lymphocytes. J. Immunol. 130:2568-2573.

15. Grupp, S. A., and J. A. L. Harmony. 1985. Increased phosphatidylinositol metabolism is an important but not an obligatory early event in B lymphocyte activation. J. Immunol. 134:4087-4094.

16. Rigley, K. P., M. M. Harnett, R. J. Phillips, and G. G. B. Klaus. 1989. Analysis of signaling via surface immunoglobulin receptors on B cells from CBA/ N mice. Eur. J. Immunol. 19:2081-2086.

17. Mills, G. B., R. K. Cheung, S. Grinstein, and E. W. Gelfand. 1985. Interleukin 2-induced lymphocyte proliferation is dependent on increases in cytosolicfree calcium concentrations. J. Immunol. 134:2431-2435.

18. Margolis, B., A. Zilberstein, C. Franks, S. Felder, S. Kremer, A. Ullrich, S. G. Rhee, K. Skorecki, and J. Schlessinger. 1990. Effect of phospholipase C- $\gamma$ overexpression on PDGF-induced second messengers and mitogenesis. Science (Wash. DC). 248:607-610.

19. Mills, G. B., D. Stewart, A. Mellors, and E. W. Gelfand. 1986. Interleukin2 does not induce phosphatidylinositide hydrolysis in activated T cells. J. Immunol. 136:3019-3024.

20. Kamps, M. P., and B. M. Sefton. 1988. Identification of multiple novel polypeptide substrates of the v-src, v-yes, v-fps, v-ros, and v-erb-B oncogenic tyrosine protein kinases utilizing antisera against phosphotyrosine. Oncogene. 2:305-315.

21. Ledbetter, J. A., N. K. Tonks, E. H. Fischer, and E. A. Clark. 1988. CD45 regulates signal transduction and lymphocyte activation by specific association with receptor molecules on T or B cells. Proc. Natl. Acad. Sci. USA. 85:86288632.

22. Sekar, M. C., and B. D. Roufogalis. 1984. Muscarinic-receptor stimulation enhances polyphosphinositide breakdown in guinea pig ileum smooth muscle. Biochem. J. 223:527-531.
23. Holub, B. J. 1974. The $\mathrm{Mn}^{2+}$-activated incorporation of inositol into molecular species of phosphatidylinositol in rat liver microsomes. Biochem. Biophys. Acta. 369:111-122.

24. Carter, R. H., D. J. Park, S. G. Rhee, and D. T. Fearon. 1991. Tyrosine phosphorylation of phospholipase $\mathrm{C}$ induced by membrane immunoglobulin in B lymphocytes. Proc. Natl. Acad. Sci. USA. 88:2745-2749.

25. Reth, M., J. Homback, J. Wienands, K. S. Campbell, N. Chien, L. B. Justement, and J. C. Cambier. 1991. The B-cell antigen receptor complex. Immunol. Today. 12:196-200.

26. Ales-Martinez, J. E., E. Cuende, C. Martinez-A., R. M. E. Parkhouse, L. Pezzi, and D. W. Scott. 1991. Signaling in B cells. Immunol. Today. 12:201-205.

27. Sakaguchi, N., S. Kashiwamura, M. Kimoto, P. Thalmann, and F. Melchers. 1988. B-lymphocyte lineage-restricted expression of mb-1, a gene with CD3-like structural properties. EMBO (Eur. Mol. Biol. Organ.) J. 7:3457-3464.

28. Hombach, J., T. Tsubata, L. Leclercq, H. Stappert, and M. Reth. 1990 Molecular components of the B-cell antigen receptor complex of the IgM class. Nature (Lond.). 343:760-762.

29. van Noesel, C. J. M., R. A. W. van Lier, J. L. Cordell, A. G. D. Tse, G. M. W. van Schijndel, E. F. R. de Vries, D. Y. Mason, and J. Borst. 1991. The membrane IgM-associated heterodimer on human B cells in a newly defined B cell antigen that contains the protein product of the mb-l gene. J. Immunol. 146:3881-3888.

30. Campbell, K. S., E. J. Hager, R. J. Friedrich, and J. C. Cambier. 1991. IgM antigen receptor complex contains phosphoprotein products of B29 and mb-1 genes. Proc. Natl. Acad. Sci. USA. 88:3982-3986.

31. Chen, J., A. M. Stall, L. A. Herzenberg, and L. A. Herzenberg. 1990. Differences in glycoprotein complexes associated with IgM and IgD on normal murine B cells potentially enable transduction of different signals. EMBO (Eur. Mol. Biol. Organ.) J. 9:2117-2124.

32. Gold, M. R., J. P. Jakeway, and A. L. DeFranco. 1987. Involvement of a guanine nucleotide-binding component in membrane IgM-stimulated phosphoinositide breakdown. J. Immunol. 139:3604-3613.

33. Harnett, M., and G. G. B. Klaus. 1988. G protein coupling of antigen receptor-stimulated polyphosphoinositide hydrolysis in B cells. J. Immunol. 140:3135-3139.

34. Harnett, M. M., and G. G. B. Klaus. 1988. G protein regulation of receptor signaling. Immunol. Today. 9:315-320.

35. Justement, L. B., J. Wienands, J. Hombach, M. Reth, and J. C. Cambier. 1990. Membrane IgM and IgD molecules fail to transduce $\mathrm{Ca}^{2+}$ mobilizing signals when expressed on differentiated B lineage cells. J. Immunol. 144:32723280 .

36. Nasmith, P. E., G. B. Mills, and S. Grinstein. 1989. Guanine nucleotides induce tyrosine phosphorylation and activation of the respiratory burst in neutrophils. Biochem. J. 257:893-897.

37. Yamanashi, Y., T. Kakiuchi, J. Mizuguchi, T. Yamamoto, and K. Toyoshima. 1991. Association of B cell antigen receptor with protein tyrosine kinase lyn. Science (Wash. DC). 251:192-194.

38. Dymecki, S. M., J. E. Niederhuber, and S. V. Desiderio. 1990. Specific expression of a tyrosine kinase gene, blk, in B lymphoid cells. Nature (Lond.). 247:332-336.

39. Charbonneau, J., N. K. Tonks, K. A. Walsh, and E. H. Fischer. 1988. The leukocyte common antigen (CD45): a putative receptor-linked protein tyrosine phosphatase. Proc. Natl. Acad. Sci. USA. 85:7182-7186.

40. Tonks, N. K., H. Charbonneau, C. D. Diltz, E. H. Fischer, and K. A. Walsh. 1988. Demonstration that the leukocyte common antigen CD45 is a protein tyrosine phosphatase. Biochemistry. 27:8695-9701.

41. Brunswick, M., F. D. Finkelman, P. F. Highest, J. K. Inman, H. M. Dintzis, and J. J. Mond. 1988. Picogram quantities of anti-Ig antibodies coupled to dextran induce B cell proliferation. J. Immunol. 140:3364-3372. 